\title{
Editorial
}

\section{Decolonising the South African prison}

\section{Nontsasa Nako}

nnako@uj.ac.za

http://dx.doi.org/10.17159/2413-3108/2018/i66a5649

Prisons have been in the news in South Africa in the past two years: from the stripper scandal, ${ }^{1}$ where saucily dressed women were snuck into Johannesburg Correctional Centre to entertain the inmates, to frequent reports of stabbings in prisons across the country, and of course, the unrest at the St Albans Maximum Security Prison in Port Elizabeth, where three inmates lost their lives at the end of 2016. ${ }^{2}$ More recently, prisons made headlines with the revelations at the Commission of Enquiry into State Capture about massive corruption involving high-ranking government and ANC officials, and a security company called Bosasa (now African Global Operations), which manages detention facilities in South Africa. Ranging from lurid to frightening, tragic and disturbing, these frequent media reports have kept the public's gaze squarely on prisons, exposing the greed and abuse that undergird our system of crime and punishment in the country. But these reports have only addressed the prison as a place and not as an institution. That is, while these reports may raise debates about the role of the prison in the criminal justice system, they have not questioned incarceration as an institution, and its role in a constitutional democracy.

This special edition attempts to do both - to think of the day-to-day function of the prison and also to confront the wider impact of imprisonment on various communities through the lens of decolonisation. The prison, as a place of exclusion and legitimate expression of state power, has a critical role to play in South Africa's decolonisation project. Decolonisation is itself a struggle against domination, particularly domination that stems from colonialism and its enduring institutions. Gatsheni urges us to consider 'how the current modern global coloniality and capitalist structure re-emerged, was organized, configured and articulated according to the imperatives of global imperial designs' ${ }^{3}$ in understanding the global designs of colonialism. Given the prison's centrality in constructing colonial modernity's domination, it is an appropriate target for decolonisation. We should not lose sight of its oppressive presence in our society.

Whether decolonisation will mean the complete destruction of colonial institutions, or rather require tweaking them to better accommodate the formerly colonised and oppressed, is a much larger debate. This special edition is concerned with describing the status quo in terms of prisons and imprisonment, and understanding how the marginalised fare in the current systems. We may start by asking how those who expend their resources and energies exposing the perfidies of legal systems, for example activists and criminalised communities, continue to appeal to these selfsame systems in pursuit of justice and equity. This is the question with which Thato Masiangoako's 'Rationalising injustice: the reinforcement of legal hegemony in South Africa' engages. Her 
article explains the frames of rationalisation employed by migrants and student and community activists, who were victims of police violence due to their perceived activist or migrant status. By explicating the discursive frames that legitimise legal hegemony, Masiangoako's article helps us understand how enduring cultural, social and institutional histories shape popular perceptions and may account for 'the enduring nature of prison', despite Masiangoako's experiences of unfair detention among these migrants and student and community activists.

In South Africa, where nearly a third of those incarcerated are awaiting trial, the deleterious impact of crime and punishment on the poor and marginalised is clear. Palesa Madi and Lubabalo Mabhenxa's article, 'Possibly unconstitutional?: The insistence on verification of address in bail hearings', analyses the bureaucracy of detention and finds that the requirement to verify addresses makes it difficult for the poor and marginalised to be released on bail. The criterion of fixed address as a bail condition for awaiting trial inmates places an undue burden on itinerant and displaced persons in a country where it is not uncommon for people to lack fixed homes. Further, because there is no uniformity in how this criterion is applied, different courts apply different standards. The authors conclude that with the remand detainee population so high in South African prisons, the existing instruments that protect the rights of detainees, including the right to liberty, the right to be presumed innocent, the right to equality and the right to be detained only as a measure of last resort, should be utilised in order to bring South Africa in line with international human rights law.

However, as Untalimile Crystal Mokoena and Emma Charlene Lubaale argue in 'The need for effective bail affordability inquiries', whether through bail, or verification of address as a condition for granting bail, remand conditions, as they stand, create unequal access to justice. These authors argue that bail affordability is a paramount consideration if we want to ensure that there is equality before the law and that the dignity of the indigent accused is protected. Both articles place emphasis on international laws and appeal to universal human rights discourses, and as such, both rely on colonial modernity to make the case for equitable dispensation of justice. We may well ask whether this goes far enough toward decolonising prisons, or whether there are other ways in which we can be more responsive to local colonial realities.

Global capital flows have retarded the progress of social justice, and there are contextual and historical conditions in South Africa that give these flows a distinctive local colour. For instance, while the prison industrial complex is a global phenomenon, it finds its grossest manifestation yet in the recent revelations about the corrupt entanglements of Bosasa and high-ranking government and ANC officials. If Angelo Agrizzi's explosive testimony at the Commission of Enquiry into State Capture is to be believed, those tasked with the administration of justice manipulated social problems to enrich themselves, at the expense of the poor and marginalised. Anthony Kaziboni's piece on the Lindela Reparation Centre is timely and relevant as it uncovers the crude manipulation of social problems for the benefit of a security company. Drawing on Giorgio Agamben's concept of 'bare life' described in Homo sacer: sovereign power and bare life, Kaziboni follows media reports on Lindela over a period of 18 years to identify what he terms 'xenophobic biopower', wherein immigrants detained at the centre are presented as negatives in South Africa. Perhaps, Agamben's 'bare life' usefully aligns with Mbembe's categories of colonial violence, ${ }^{4}$ particularly the legitimisation of violence through institutions such as prisons. Kaziboni shows that in Agamben's state of exception, there is no distinction between violence and the law, and, as such, violence is intrinsic to the juridical. ${ }^{5}$ He argues that when the detained immigrants are constituted 
as exceptional, and when their rights are suspended due to 'illegality', all manner of violence against them is permissible. The article forces us to ask ourselves what we make of this 'rightless condition', where 'the normal order is de facto suspended'. ${ }^{6}$ The reader is left questioning whether decolonisation of our prisons requires envisioning new spaces, or whether we can improve the existing juridical order.

The outsourcing of important state functions like security, crime and punishment risks eroding public trust in the state's ability to dispense justice. Of course, while we focus on the South African prison, this special edition emerged out of a 2017 conference hosted by the University of Johannesburg's Centre for Social Change entitled 'The Global Prison', during which the state of prisons and incarceration globally was discussed by scholars, practitioners and activists. Presentations at that conference explored the many facets of crime and punishment globally, especially the way in which neoliberal globalisation retards social justice advancement towards real prison reform or even decarceration. Instead, progress is marked by advances in incarceration technologies which do nothing to advance social justice, and in fact entrench state power. Our system remains caught up in what Loïc Wacquant describes as a paradox of neoliberal penality where 'the state stridently reasserts its responsibility, potency, and efficiency in the narrow register of crime management at the very moment when it proclaims and organizes its own impotence on the economic front, thereby revitalizing the twin historical-cum-scholarly myths of the efficient police and the free market.' ${ }^{\text {' }}$ Clearly, advancements in policing and prison technologies owe their genesis to colonial global designs. So, decolonisation must attend to the definition of modernity which feeds the drive for the most technologically advanced institutions, even when they displace the marginalised and poor think housing developments, airports and shopping malls - or legitimise violence, like the prison. In a marked departure from the conference themes, though, we focus on what decolonisation would mean for the South African prison, given the country's history and national aspirations.

Decolonising prison, or any other institution, will have to centre on defining, identifying and describing our realities in our terms. It is not enough to speak of colonisation as if there have been no intervening social orders. The South African Truth and Reconciliation Commission (TRC), for instance, sought to mitigate the effects of apartheid, which was a spawn of colonialism and produced particularly harsh realities for the majority of South Africans. But, from these contributions, it is clear that not enough has been done to extend the gains of the TRC (such as they were). Clearly, apartheid forged various categories of racial and gendered identities from colonial taxonomies, but their persistence in post-apartheid South Africa is puzzling and calls for closer scrutiny. When it comes to decolonisation of prison therefore we have to look at the history of detention and imprisonment to see how it shapes the present. As Judge Jody Kollapen suggests in 'On the Record', decolonisation is a broad concept, and the high rate of crime places undue focus on crime and punishment rather than on the various factors that produce social malaise, therefore contributions such as the essays in this volume help in expanding our knowledge and might ultimately guide us towards the decolonisation of institutions such as prisons.

\section{Notes}

This issue of South African Crime Quarterly was made possible by funding from the National Institute for the Humanities and Social Sciences (NIHSS) Working Group Fund.

1 T Khubeka, Full investigation underway into prison stripper incident - commissioner, EWN, 27 June 2017, https://ewn. co.za/2017/06/27/officials-linked-to-prison-strip-show-to-face-consequences 
2 D Spies, 'Worst of the worst' inmates behind attack on St Albans prison guards, news24, 27 December 2016, https://www.news24. com/SouthAfrica/News/worst-of-the-worst-inmates-behind-attack-on-st-albans-prison-guards-20161227

3 J Sabelo and G Ndlovu, Empire, global coloniality and African subjectivity, New York and Oxford: Berghahn Books, $2013,53$.

4 Achile Mbembe, cited in ibid., 51.

5 G Agamben, State of exception, Chicago: University of Chicago Press, 1998, 6.

6 Ibid., 174.

7 L Wacquant, Punishing the poor: the neoliberal government of social insecurity, Durham: Duke University Press, 2009, xviii. 